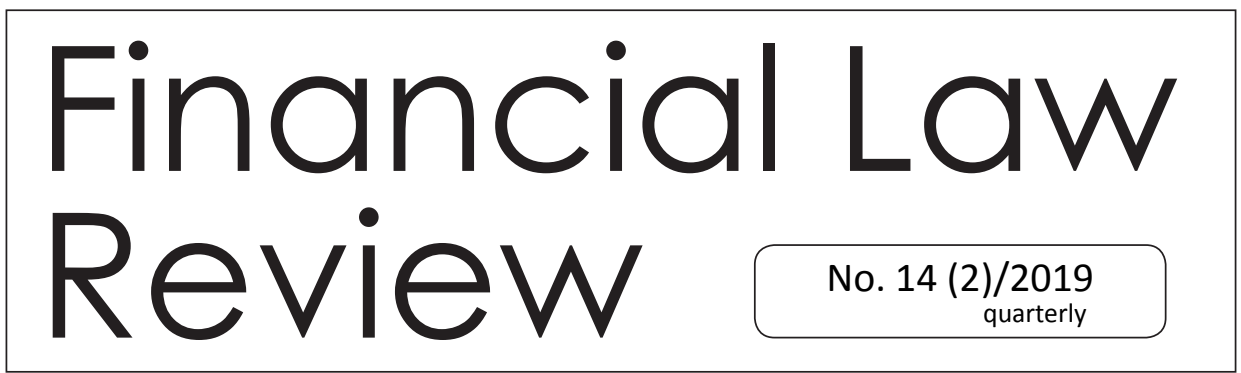

UNIVERSITY OF GDAŃSK • MASARYK UNIVERSITY • PAVEL JOZEF ŠAFÁRIK UNIVERSITY • UNIVERSITY OF VORONEZH http://www.ejournals.eu $\bullet$ http://czasopisma.bg.ug.edu.pl

\title{
MEASURES TO COUNTER TAX EVASION: INTERNATIONAL AND RUSSIAN EXPERIENCE ANDREY KRASYUKOV*
}

\begin{abstract}
The article is devoted to such actual method of tax evasion as a bypass of the law. The main purpose of this contribution is to figure out the most effective way to counter tax evasion. The following scientific methods were used in this study: analysis, comparative study, and others. The article describes the most common tax legal doctrines both in Russia and in foreign countries. The author comes to the conclusion that the most effective way to counter tax evasion would be applying judicial legal doctrines. According to the results of the study, the author comes to the conclusion that it is necessary to implement certain judicial legal doctrines into Russian tax legislation.
\end{abstract}

\section{Keywords:}

Tax evasion, circumvention of the law, judicial legal doctrine, corporate veil.

JEL Classification: K340.

\footnotetext{
$\mathrm{PhD}$ in Law, Associate Professor of the Department of Financial Law of the Faculty of Law of Voronezh State University, specializes in the field of tax and legal regulation of property relations, the author of more than 30 articles in peer-reviewed journals, a member of the Center for Public Finance and Tax Law of Central and Eastern Europe, kav@law.vsu.ru
} 


\section{Introduction}

Recently, taxpayers' actions have been aimed at tax evasion but formally these actions are fully compliant with current legislation, which has become an increasing problem (Skalicka, 2015: 192-211). This behavior of the taxpayer is usually described as a circumvention of the law.

A transaction is deemed to be accomplished in circumvention of the law when it conforms to the law in its content, but as a result of this transaction, in conjunction with other circumstances, that doesn't meet the requirements of law (Muranov, 1999: 30). The conclusion of a transaction through a conduit company the tax regime of which is of a preferential nature is an example of such circumvention.

In foreign legal science, "circumvention" and "avoidance" of the law are divided. There is a ban on the "bypass" of parliamentary law: the court is obliged to interpret every law in such a way that truly prohibited acts or omissions do not entail legal consequences in any case. On the other hand, it is allowed to "avoid" what is forbidden by parliamentary law, while doing something equally beneficial for you and not prohibited by law. If actions fall under the prohibition of the law, then there would be the first type of detour. If they do not fall, then it is the second type of detour, i.e., the "avoidance" of the application of the law that does not cause any adverse consequences (The Encyclopedia, 1940: 398-399).

It should be noted that bypassing the law in the field of taxation can be carried out not only through the conclusion of a transaction but also through corporate relations, for example, by splitting up a business in order to preserve the right to apply special tax regimes.

Thus, the circumvention of the law is a figurative collective expression (to mark a number of inherently unlawful actions that are attempted to give the appearance of legality based on the letter of the law. According to individual researchers, the content of this concept is exhausted by the simple designation of a set of such actions, and it has no independent legal specificity, since all actions designated by the term "circumvention of the law" have only two common features: 1) objective illegality of these actions and 2) the appearance of legality in their presence (Muranov, 1999: 9-12).

It is difficult to agree with this statement, since the legal specifics of this phenomenon fully correspond to the legal nature of the subjective right abuse. When traversing the law, the subject uses the rights granted to him by law to conclude transactions and form legal entities in order to create imitation conditions for 
obtaining a tax benefit to which he is not entitled on the basis of the nature of his obligations and corporate relations.

Thus, in international tax law, circumvention of the law is used in an effort to apply the required double taxation agreement to tax relations, i.e. to get under the desired tax jurisdiction by distorting the ownership structure of the subject of taxation or the structure of the transaction.

Simple application of current legislation is not enough for countering this form of tax evasion, because the behavior of the taxpayer does not contradict the letter of the law (Romanova, 2015: 212-228). It seems necessary to identify the essence of the law, its meaning. Therefore, the most effective way to counter this form of tax evasion is applying legal doctrines developed in judicial practice.

\section{Chapter I. Legal doctrines as a means of countering tax evasion: international experience}

Legal doctrines made up during judicial law-making are currently used to combat various types of tax deviation of taxpayers. Many of these doctrines used in Russia today have been borrowed from other states. So, in the tax law of the United States there are the following options for judicial doctrines aimed at identifying the deviant behavior of the taxpayer (Congress of the United States, 1999):

1. The doctrine of "simulated transactions" (sham transactions), i.e. transactions that are imitated by the parties and are not actually carried out are concluded only for visibility.

The simulation is divided into:

- Simulation of the fact of the transaction (sham in fact), i.e. tax-oriented transactions are not actually concluded (Eli D. Goodstein et al., Petitioners, v. Commissioner of Internal Revenue);

- simulation of the transaction content (sham in substance), i.e. tax-oriented transactions are actually concluded, but executed only to the extent necessary for the desired tax consequences, without giving rise to civil-legal consequences (Asa Investerings Partnership, et al. v. Commissioner of Internal Revenue);

2. The doctrine of the economic substance (economic substance), intended to determine the tax consequences of real transactions that have no economic sense, separable from obtaining tax benefits. A transaction may be recorded for tax purposes if it has a business purpose, i.e. dictated by business or management goals, 
inspired by non-tax considerations, and its legal form was chosen not only under the influence of the intention to avoid taxation by giving it meaningless legal names (Frank Lyon Company v. United States).

3. The "substance over form" doctrine implies the determination of the tax consequences of the transaction basing not on its name, and form, but on its real economic content, and essence. Thus, transactions which are different in form and have an identical economic result should not be taxed in different ways only because this result is achieved by various legal means (Minnesota Tea Co. v. Helvering, Commissioner of Internal Revenue).

In France, Art. L 64 of the Code of Fiscal Procedures (Livre des procedures fiscales), states that the realization of the powers of tax administration cannot be made dependent on an action that conceals the true essence of the contract. The true nature of the contract is established out of court by the tax administration. At the same time, scientists in France accept that actions aimed at full or partial exemption from taxation can be recognized as the abuse of the right (abus de droit) (Bouvier, 2000: 51).

4. The "step by step" doctrine is used in the tax qualification of a set of transactions that are considered by the courts as part of a single complex transaction (intermediate or non-binding elements in such transactions can be ignored when determining the tax consequences of such transaction) (Commissioner of Internal Revenue v. Gordon).

\section{Chapter II. Legal doctrines as a means of countering tax evasion: Russian experience}

The judicial doctrines existing in the Russian judicial practice used to counteract the deviant behavior of a taxpayer can be divided into two types:

- special tax, i.e., designed specifically for tax purposes;

- interdisciplinary, mostly rooted in civil law.

The first type should be attributed to the doctrine of "bad faith of the taxpayer", "the validity of the tax benefit." The second doctrine is complex, since it is based on a number of other aforementioned judicial doctrines, developed primarily in states with common law system. The second type of doctrines includes the doctrines of "abuse of the right" and "a transaction contrary to the basis of law and order" (at present, it is practically not used for tax purposes). 
The doctrine of bad faith of the taxpayer. In the theory of tax law and judicial practice, researchers generally try to bring the deviant behavior of a taxpayer under one basis, to give it a unified characterization. Initially, at the suggestion of the Constitutional Court of the Russian Federation, such behavior was usually characterized as unfair. However, the extremely broad definition, based primarily on moral and ethical principles, could not satisfy the specialists and clarify the tax regulation. When the right begins to use predominantly estimated categories, it closes in with the morale, collapses (Savseris, 2007: 12).

However, it is hardly possible to completely exclude assessment categories from the arsenal of tax and legal regulation. Valuation concepts which have moral characteristic appear in tax law due to a wide subject of legal regulation, when participants of public relations largely model their own behavior at their discretion.

As a general rule in the public sphere such freedom of conduct is not possible. However, in tax law, the subject of regulation is relations derived from civilian traffic, which gives rise to some freedom in their modeling and the need for the above instruments. By virtue of this, individualization of legal regulation in tax legal relations cannot be carried out without the use of moral principles. This is due to the fact that the scope of moral norms is wider than the scope of the law.

However, the side of tax legal relations, unlike the court, is not obliged, and often cannot be guided by objective moral criteria. For taxpayers, moral criteria almost always have a specific subjective character. Therefore, the criterion of good faith allows us to establish the internal limits of the exercise of subjective right, but these limits of the behavior of the bearer of rights themselves always have a subjective character (Malinovskiy, 2007: 159).

By virtue of this, the use of the concept of the taxpayer's good faith did not help to streamline tax and legal regulation and to highlight objective criteria that make it possible to distinguish the deviant behavior of the taxpayer from the legitimate.

The concept of tax profitability, which replaced the taxpayer's good faith doctrine, attempted to overcome these shortcomings by highlighting the common goal of all options for deviating taxpayer's behavior. The receipt of unjustified tax benefit was presumed as such goal. However, such perfectly true generalization also suffers from the subjectivity of the criteria for evaluating the validity of the tax benefit, which makes it difficult to apply the concept in practice and gives rise to many disputes and conflicts. At the same time, the legal nature of the taxpayer's actions aimed at obtaining an unjustified tax benefit is ignored, with the result 
that the same legal consequences cause different phenomena in their essence: both offences and abuse of law.

Logically, scholars divide all of the schemes for obtaining tax benefit into the following types: 1) cashing out taxpayer's money through civil-legal contracts; 2) the fractionation of the taxpayer's business in order to reduce taxes through the use of nominees; 3) the use of special tax regimes; 4) the use of tax incentives; 5) understatement of the tax base (overpayment or taxpayer deduction) through various mock and sham transactions; 6) the use of foreign low-tax jurisdictions (Volkov, 2018: 23-27).

In our opinion, this classification is a clear illustration of the heterogeneity of those phenomena that are included in the unified concept of unjustified tax benefit.

Abuse of law. An attempt to describe the deviant behavior of a taxpayer through the legal construction of abuse of the right in Russia was unsuccessful although a similar concept of "abnormal acts of management" (acte anormal de gestion) is quite successfully used in foreign judicial practice. According to the practice of the State Council of France, the deviant behavior of a taxpayer means actions connected with shifting expenses or expenses to an organization's account, or actions that deprive it (organization) of receipts (and the corresponding actions cannot be justified by the interests of commercial activity) (Vinnitskiy, 2003).

The abuses on the part of the participants in the economic turnover causing problems of a fiscal nature are primarily concentrated in such areas as:

- pricing in transactions between related parties;

- the use of intermediate (conduit) companies (conduit companies / entities) to access the benefits provided for in international treaties for the avoidance of double taxation and for the prevention of tax evasion;

- obtaining unjustified tax benefits;

- evasion from payment of the arrears revealed as a result of tax control (Havanova, 2018: 112-122).

In our opinion, if transfer pricing and the use of conduit companies can be characterized as an abuse of a subjective right, then evading payment of arrears is a direct violation of the law and cannot be attributed to the abuse of a subjective right. Receiving unjustified tax benefits is the result of abuse or misdemeanor, not abuse. Thus, an attempt to include all possible variants of tax deviation in abuse is hardly justified. 


\section{Chapter 3. The implementation of foreign legal doctrines into Russian tax legislation}

At present, in Russian legal reality countermeasures to the formal use of the construction of a legal entity for tax evasion are carried out with the help of: 1) universal measures (for example, the doctrine of unjustified tax benefit); 2) special measures (for example, transfer pricing rules); 3 ) measures to counter offshoring business (for example, the rules for taxing profits of controlled foreign companies) (Havanova, 2018: 112-122).

However, these measures cannot be called effective because they are either private (transfer pricing and de-offshore), or not statutory and too abstract (unreasonable tax benefit). In our opinion, the universal key to solving this problem should be sought in the concept of tax law autonomy, which allows for a different assessment of the relations of the participants in civilian turnover for tax purposes, including penetrating corporate relations behind the veil without affecting their validity in the sphere of civil turnover.

The protection provided by the corporate veil is not absolute, and only the legitimate behavior of shareholders creates the necessary conditions for its legal integrity. In some cases, in tax legislation and judicial practice, the principle of legal penetration for corporate coverages is used to retrain corporate relations. The legal literature identifies the main types of penetration for corporate covers in the field of tax legal relations: direct - from the company to the participants (shareholders); the opposite is from the participant (shareholder) to the company; fan - in relation to several interdependent persons who make up the economic community.

At present, the following institutions are enshrined in the tax legislation, which are based on the principle of legal penetration for the corporate veil:

1. A person who has a de facto right to income (beneficial owner). The basis of this institution is the postulate that the right to use the tax relief provided by the international agreement on the avoidance of double taxation belongs only to the real beneficiary (recipient) of income, who bears all the risks of investing and fully disposes of the funds received. Under this mechanism, tax authorities have the right to recognize a person other than the nominal recipient as the real income recipient.

2. Controlled foreign company. Such legal constructions - equating the profit of a foreign company with the income (profit) of a Russian resident - are designed to prevent the loss of government revenues. It is based on the principle of imputation of 
income to a subject that is not yet formally its beneficiary, but has a real (sufficient) possibility of control over a foreign company. These rules should cover only those situations where there is a focus on actions to reduce or postpone (in time) the fulfillment of a tax obligation (for example, the incorporation of a foreign company in a low tax jurisdiction and the prolonged accumulation of money there in the absence of an active entrepreneurial business / activities) (Havanova, 2018: 112-122).

3. Consolidated group of taxpayers. This institute makes it possible to jointly calculate the profit tax of organizations to different taxpayers but belonging to the same person. Thus, the factor of formal separation of legal entities is inferior to the economic factor of ownership.

The judicial practice has also developed and has recently actively applied the institution of the subsidiary responsibility of managers and beneficiaries of an organization that is a taxpayer for tax debts. This legal mechanism, in our opinion, is also subject to consolidation in tax legislation.

\section{Conclusion}

The above institutions and doctrines in their purpose allow to counteract only certain forms of tax evasion, not having a universal character. In this regard, it is necessary to consider the possibility of legislatively securing the authority of tax authorities to retrain corporate relations of taxpayers, if their structure is an imitation of corporate relations aimed at unjustified receipt of tax preferences.

For such retraining, it is necessary to establish the presence of certain criteria indicating evasion of tax payment. Each of the above doctrines uses a certain criterion to distinguish tax evasion from the lawful behavior of a taxpayer, which must be proved in a particular tax dispute. The following main criteria can be distinguished:

- business purpose;

- control;

- economic consequences.

In the framework of judicial doctrines funds for their implementation should be allocated:

- reconstruction of legal consequences - the main means of preventing tax evasion;

- subsidiary liability. 
When legislatively establishing an extended mechanism of sub-safety liability, a number of fundamental rules should be provided for the application of subsidiary liability for tax debts.

Firstly, it is not the formal managers and founders of the taxpayer who are to be brought to subsidiary responsibility, but the real beneficiaries and persons who actually manage their activities.

Secondly, it is necessary to take into account the causes of arrears. Attraction is possible only if there are signs of tax evasion in the behavior of the above persons.

Thirdly, subsidiary liability is possible only after the exhaustion of all measures of compulsory collection of debt from the taxpayer provided for by law.

\section{Bibliography:}

1. Asa Investerings Partnership, et al. v. Commissioner of Internal Revenue, 340 U.S. App. D.C. 55; 201 F.3d 505; 2000 U.S. App. LEXIS 1207; 2000 - 1 U.S. Tax Cas. (CCH) P50, 185; 85 A.F.T.R.2d (RIA) 675 (United States Court of Appeals for the District of Columbia Circuit; Argued Oct. 19, 1999; Decided Feb. 1, 2000) // http://www.irs.gov.

2. Bouvier, M.: Introduction au droit fiscal general et a la theorie de limpot (Introduction to general tax law and the theory of taxation), Paris: L.G.D.J., 2000.

3. Congress of the United States, Joint Committee on Taxation, (JCX-84-99) Nov. 10, 1999. Appendix II To JCX-82-99: Description And Analysis Of Present-Law Tax Rules And Recent Proposals Relating To Corporate Tax Shelters. https://www.jct.gov.

4. Commissioner of Internal Revenue v. Gordon, 391 U.S. 83 (1968; Argued Apr. 4, 1968; Decided May 20, 1968). http://supreme.justia.com.

5. Eli D. Goodstein et al., Petitioners, v. Commissioner of Internal Revenue, 267 F.2d 127 (United States Court of Appeals First Circuit, May 21, 1959). http://bulk.resource.org.

6. Havanova, I.A.: Vzaimozavisimye litsa: korporativnye pokrovy I fiskalnye problem (Interdependent entities: corporate coverages and fiscal issues), Zhurnal rossyskogo prava (Journal of Russian Law) no. 7 (2018).

7. Frank Lyon Company v. United States, 435 U.S. 561 (1978; Argued Nov. 2, 1977; Decided Apr. 18, 1978). http://www.law.cornell.edu.

8. Malinovskiy, A.A.: Zloupotreblenie subectivnym pravom (teoretiko-pravovoe issledovanie) (Subjective law abuse (theoretical and legal research), Moscow, 2007.

9. Minnesota Tea Co. v. Helvering, Commissioner of Internal Revenue (1938; Argued Dec. 16, 1937; Decided Jan. 17, 1938) 302 U.S. 609, 613 (1938). http://www.law.cornell. edu. 
10. Muranov, A.I.: Problema "obhoda zakona" v materialnon i kollisionnom prave (The problem of "circumvention of the law" in the material and conflict of laws): avtoreferat dissertatsii (dissertation), Moscow, 1999.

11. Romanova, A.: The New Anti Abuse Rule in Slovak Tax Law: Strengtening of Legal Certainty? in: System of Financial Law : System of Tax, Brno : Masaryk University, Faculty of Law, 2015.

12. Savseris, S.V.: Kategoriya "nedobrosovestnost" v nalogovom prave (Category "bad faith" in tax law), Moscow: Statut, 2007.

13. Skalicka, H.: Abuse of Law - Influence of Case Law of Court of Justice of the European Union on the Taxation in the Czech Republic, in: System of Financial Law : System of Tax, Brno : Masaryk University, Faculty of Law, 2015.

14. The Encyclopedia of words and phrases. Legal maxims. Canada. 1825-1940. Vol. I.

15. Vinnitskiy, D.V.: Princip dobrosovestnosti i zloupotreblenie pravom v sfere nalogooblozheniya (The principle of good faith and abuse of the right in the field of taxation), Pravo i ekonomika (Law and economics) no. 1 (2003).

16. Volkov, A.V.: Konec epohi “optimizacii nalogov" v predprinimatelskoy deyatelnosty (The end of the era of "tax optimization" in business), Zhurnal predprinimatelskogo korporativnogo prava (Journal of Business Law) no. 3 (2018). 